\title{
Comparison of the Morphology, Fermentation, Assimilation, Lipid Content and Mannans of Rough and Smooth Strains of Saccharomyces cerevisiae
}

\author{
By L. MASLER, D. ŠIKL, A. KOCKOVÁ-KRATOCHVÍLOVÁ \\ AND S̆. BAUER \\ Institute of Chemistry of the Slovak Academy of Sciences, \\ Bratislava, Czechoslovakia
}

(Accepted for publication 9 December 1970)

\begin{abstract}
SUMMARY
Tetrad analysis has shown that haploid forms arising from spores of a single ascus of Saccharomyces cerevisiae gave smooth and rough strains in the ratio $\mathrm{I}: \mathrm{I}$. These rough and smooth strains fermented the same sugars but differed in their morphology, mode of L-lysine assimilation and lipid content. Immunochemical studies, periodate oxidation and methylation analyses showed that both strains formed the same kind of mannan.
\end{abstract}

\section{INTRODUCTION}

In some yeast species a spontaneous transformation of smooth strains into rough strains has been observed (Kreger-van Rij, 1969). This transformation is associated with biochemical and morphological changes. Differences between smooth and rough forms occur in the adsorption of surface active cationic substances (Šilhánková, 1957). Furthermore, rough forms are hydrophobic and more resistant to lysis by snail juice enzymes (Millbank \& Macrae, 1964). Wickerham \& Barton (1962) suggested that these hydrophobic properties might be related to the presence of sphingolipids on the cell surface. Kauppinen, Kiviniemi \& Erkama (1965) have found that walls of rough strains of Candida guilliermondii contain $50 \%$ more lipid than smooth strains. In the genus Salmonella changes in antigenic properties of the cell surface result from rough mutants being unable to synthesize complete $\mathrm{O}$-specific polysaccharides (Lüderitz \& Westphal, 1966). It would be of interest to determine if there are similar changes in surface layers of walls of rough strains of yeasts.

The purpose of our present work was to elucidate differences in morphology, lipid content, antigenic properties, assimilation and fermentative abilities of rough and smooth strains of Saccharomyces cerevisae.

\section{METHODS}

Organisms and media. The monosporogenous cultures used in our study were isolated in 1964 from Saccharomyces cerevisiae IXL-A $\mathbf{A}_{3}$ (a commercial yeast strain from England) by micromanipulation. In the present study four strains $(64 / \mathrm{I}-4)$ arising from the same ascus were used. Their fermentation and assimilation properties were 
studied using methods described previously (Kocková-Kratochvilová, 1954). The strains were obtained from the Yeast Division of the Czechoslovak Collection of Micro-organisms (CCY), Institute of Chemistry of the Slovak Academy of Sciences. Further, a non-sporogenous mutant ( $\mathrm{s}_{3} \mathrm{I} 3 / \mathrm{I}$ ) was obtained from the smooth strain $64 / 2$ by culturing the organism at $28^{\circ}$ in media $\left(2 \%\right.$ (w/v) glucose, $\mathrm{I} \%(\mathrm{w} / \mathrm{v}) \mathrm{NH}_{4}{ }_{2} \mathrm{SO}_{4}$; $0 . \mathrm{I} \%(\mathrm{w} / \mathrm{v}) \mathrm{KH}_{2} \mathrm{PO}_{4}$ and $0.05 \%(\mathrm{w} / \mathrm{v}) \mathrm{MgSO}_{4} \cdot 7 \mathrm{H}_{2} \mathrm{O}$ in distilled water) containing I to $3 \mathrm{mg} . / \mathrm{l}$. acriflavin. Either $2 \mu \mathrm{g}$. of biotin $/ \mathrm{ml}$. or $0.2 \%(\mathrm{w} / \mathrm{v})$ DL-serine was added (Zakharov \& Inge-Vechtomov, I966). The S. cerevisiae strain CCY 21-4-I3 was used to prepare antisera.

The culture medium and the conditions of growth of the studied strains except non-sporogenous mutants have been described previously (Masler, Šikl, Bauer \& Šandula, I966).

Lipid extraction. Lipids were extracted by the methods described by Letters (I966) and Folch, Lees \& Sloane-Stanley (1957).

Isolation of polysaccharides. (a) Extracellular mannans. The supernatant of centrifuged cultures was concentrated to $2.5 \%$ of its original volume at reduced pressure and extracellular mannans were precipitated by adding 8 volumes of ethanol. The centrifuged precipitate was dissolved in 30 -fold amounts of $5 \mathrm{~N}-\mathrm{NaOH}$ and heated for $15 \mathrm{~min}$. at $100^{\circ}$. After cooling and neutralization with conc. $\mathrm{HCl}$ the solution was dialysed against water, concentrated at reduced pressure and precipitated with 4 volumes of ethanol. After centrifugation the precipitate was dissolved in a small amount of water and lyophilized. The mannans precipitated from an aqueous solution of the polysaccharides (I \% w/v) using Fehling's reagent (Haworth, Hirst \& Isherwood, I937) were washed with ice water and suspended in water. One $\mathrm{N}-\mathrm{HCl}$ was added with stirring until the precipitate was dissolved. The solution was then passed successively through Zerolit $225\left(\mathrm{H}^{+}\right.$form) and Amberlite $402\left(\mathrm{OH}^{-}\right.$form) columns. The filtrate was concentrated in vacuo and lyophylized. The mannans obtained were free of inorganic ash and nitrogen. After hydrolysis for $6 \mathrm{~h}$. at $100^{\circ}$ in $\mathrm{I} \mathrm{N}-\mathrm{HCl}$, mannose was identified as the only monosaccharide in solvent $\mathrm{A}$ (see below) after paper chromatography.

(b) Cellular mannans. After lipid extraction the cells were suspended in a $0.2 \mathrm{M}$ $\mathrm{NaCl}$ solution (cells + solution, $\mathrm{I}+8$ by vol.) and autoclaved for $2 \mathrm{~h}$. at $150^{\circ}$. The extraction was repeated and the pooled supernatants were concentrated in vacuo and precipitated with ethanol. They were subsequently treated as described above.

Methylation analysis of the mannans. Methylation analysis was carried out according to Haworth (I9I5) in sodium hydroxide using dimethylsulphate and according to Kuhn, Trischmann \& Löw (I955) in dimethylformamide using methyliodide in the presence of silver oxide. The methylated mannans were hydrolysed in sulphuric acid as described by Croon, Herrström, Kull \& Lindberg (1960). The $O$-methylethers of D-mannose formed by hydrolysis were refluxed for $6 \mathrm{~h}$. in $5 \%(\mathrm{w} / \mathrm{w})$ methanolic $\mathrm{HCl}$ and one part of the resulting methyl-O-methyl-mannosides was analysed using gas chromatography. The remaining part of methyl-O-methyl-D-mannosides was trimethylsilylated (Sweeley, Bentley, Makita \& Wels, 1963) and then analysed using gas chromatography.

Periodate oxidation. Mannan samples (50 mg.) were dissolved in $30 \mathrm{ml}$. of water, to which $30 \mathrm{ml}$. of $0.06 \mathrm{M}-\mathrm{NaIO}_{4}$ was added. The material was stored in darkness at $4^{\circ}$. The consumption of periodate was determined using the arsenite method described 
by Fleury \& Lange (1933). The amount of formic acid produced was determined amperometrically as described by Babor, Kaláć \& Tihlárik (1964).

Chromatography. A Chrom III (Laboratory Equipments, Prague) fitted with a II $5 \times 0.6 \mathrm{~cm}$. column packed with $10 \%(\mathrm{w} / \mathrm{w})$ Carbowax 6000 on Celite 545 was used for gas chromatography. Methyl- $O$-methyl-mannosides were run at $150^{\circ}$ and trimethylsilyl derivatives at $135^{\circ}$.

The descending techniques of paper chromatography were followed with Whatman no. I paper. The following solvent systems were used: (a) butanol-I-ol+pyridine + benzene + water $(7: 3: 1: 2$, by vol., for aldoses) and $(b)$ butanol + ethanol + water ( $5: 1: 4$, by vol., for methylethers of aldoses). Aniline phthalate was used as detection reagent (Patridge, 1949).

Phosphorus determination. Phosphorus was determined by the method described by Fiske \& Subbarow (1925).

Serology. Rabbit antisera were prepared by using intravenous injections of I \% $(\mathrm{w} / \mathrm{v})$ suspensions of heat-killed cells of Saccharomyces cerevisiae $\mathrm{CCY}$ 21-4-I3. Chinchilla rabbits were used. Immunization was carried out three times a week for 5 weeks. The rabbits were bled I week after the last immunization, when the level of antibody was found to be sufficient. Antisera were preserved by addition of sodium merthiolate to achieve a concentration of $I: 10,000$ and stored at -15 to $-20^{\circ}$.

Quantitative precipitation reactions between antisera and the corresponding mannans were carried out in $0.9 \%$ aqueous $\mathrm{NaCl}$ solution with $0.2 \mathrm{ml}$. of serum and $0.8 \mathrm{ml}$. of mannan solution. Different mannan concentrations (50, I00, 150, 200, 500, 1000 $\mu \mathrm{g}$. in $\mathrm{ml}$.) were used. The polysaccharide-antiserum mixture was incubated for $2 \mathrm{~h}$. at $37^{\circ}$ followed by I week at $4^{\circ}$. The precipitate was removed by centrifugation at $4^{\circ}$, washed with ice-cold salt solution, dissolved in $0.1 \mathrm{~N}-\mathrm{NaOH}$ (I ml.) and assayed for protein spectrophotometrically at $285 \mathrm{~nm}$.

Table I. Sporulation activity of Saccharomyces cerevisiae $I X L-A_{3}$

\begin{tabular}{|c|c|c|c|}
\hline \multirow[b]{2}{*}{ Culture } & \multicolumn{2}{|c|}{ Percentage of cells producing ascospores* } & \multirow{2}{*}{$\begin{array}{c}\text { Presence of } \\
\text { diploidization } \\
\text { gene } D \dagger\end{array}$} \\
\hline & June 1969 test & December 1969 test & \\
\hline $64 / \mathrm{I}$ & 0.0 & 0.0 & - \\
\hline $64 / 2$ & 18.5 & 17.5 & + \\
\hline $64 / 3$ & 4.5 & 40 & + \\
\hline $64 / 4$ & 20.5 & $22 \cdot 5$ & + \\
\hline
\end{tabular}

RESULTS AND DISCUSSION

Tetrad analysis has shown that haploid cultures arising from the individual spores gave both smooth and rough strains in the ratio I:I (Pl. I, fig. I). The original monosporic cultures $64 / 1,64 / 2,64 / 3$ and $64 / 4$ were retested in 1969 . Two retained their original morphology (the rough strain $64 / \mathrm{I}$ and smooth strain $64 / 2$ ), while two (64/3 and 64/4) gave mixtures of rough and smooth strains (Pl. I, fig. 2 to 5). The ability of cultures to sporulate was therefore tested (Table I).

Diploid cultures of strain no. 64 form smooth colonies, but haploid strains can form rough or smooth colonies. This explains the appearance of monosporic cultures: 
strain $64 / \mathrm{I}$ has retained its rough colonial character by maintaining a haploid; strain $64 / 2$ has become a diploid and retained its smooth character; while both strains $64 / 3$ and $64 / 4$ appeared as predominantly diploid mutants showing rough sections in smooth colonies. Some morphological features of monosporic cultures $64 / \mathrm{I}-4$ are summarized in Table 2. Morphological features indicate the haploid character of strain 64/ I (high $S / V$ ratio) and the predominantly diploid character of the other cultures which is more precisely explained by Kocková-Kratochvílová \& Pokorná, 1964.

Table 2. Cell morphology of strains $64 / I-4$

\begin{tabular}{|c|c|c|c|c|c|c|c|}
\hline \multirow[b]{2}{*}{ Culture } & \multicolumn{2}{|c|}{$\begin{array}{l}\text { Average cell } \\
\text { length }\end{array}$} & \multicolumn{2}{|c|}{$\begin{array}{l}\text { Average cell } \\
\text { width }\end{array}$} & \multirow{2}{*}{$\begin{array}{l}\text { Length/ } \\
\text { width } \\
\text { ratio of } \\
\text { cells }\end{array}$} & \multirow{2}{*}{$\begin{array}{l}\text { coeff. } \\
\text { between } \\
\text { length and } \\
\text { width of } \\
\text { cells }\end{array}$} & \multirow{2}{*}{$\begin{array}{l}\text { Surface } \\
\text { volume } \\
(S / V) \\
\text { ratio of } \\
\text { cells }\end{array}$} \\
\hline & $\mu \mathrm{m}$. & S.E. & $\mu \mathrm{m}$. & S.E. & & & \\
\hline $64 / 1$ & $5 \cdot 62$ & 0.1262 & 3.78 & 0.1037 & I. 49 & 0.416 & I. 45 \\
\hline $64 / 2$ & 5.91 & 0.1165 & 5.55 & 0.1142 & I.06 & 0.864 & I.04 \\
\hline $64 / 3$ & $6 \cdot 13$ & 0.1347 & $5 \cdot 61$ & 0.1269 & $I \cdot 09$ & 0.773 & $1 \cdot 04$ \\
\hline $64 / 4$ & $5 \cdot 48$ & 0.1531 & 5.03 & 0.1496 & I.09 & 0.920 & $1 \cdot 17$ \\
\hline
\end{tabular}

Table 3. Fermentation and assimilation of cultures $64 / 1-4$

\begin{tabular}{|c|c|c|c|c|c|c|}
\hline \multirow[b]{2}{*}{ Culture } & \multicolumn{4}{|c|}{ Fermentation } & \multicolumn{2}{|c|}{ Assimilation } \\
\hline & Saccharose & Maltose & Galactose & Raffinose & $\mathrm{KNO}_{3}$ & L-Lysine \\
\hline $64 / 1$ & + & + & + & $1 / 3$ & - & $(+)$ \\
\hline $64 / 2$ & + & + & + & $1 / 3$ & - & - \\
\hline $64 / 3$ & + & + & + & $1 / 3$ & - & - \\
\hline $64 / 4$ & + & + & + & $1 / 3$ & - & $(+)$ \\
\hline
\end{tabular}

+ , Fermented; $1 / 3$, culture ferments fructose unit from raffinose after splitting it into melibiose and fructose; $(+)$, weakly assimilated; - , not assimilated.

Table 4. Biomass, lipid and mannan content of smooth $(S)$ and rough $(R)$ strains of Saccharomyces cerevisiae after 5 days incubation

$\begin{array}{ccccc}\text { Culture } & \begin{array}{c}\text { Dry weight } \\ \text { of cells* }\end{array} & \text { Lipids } \dagger & \overbrace{\text { Extracellular }}^{c} \text { Cellular } \\ \text { R 64/I } & 9.0 & 15.8 & 4.8 & 2.8 \\ \text { S 64/2 } & 14.0 & 5.0 & 3.8 & 3.5 \\ \text { S 313/I } & 2.8 & 4.8 & 1.7 & 3.3\end{array}$

* Dry wt of organism/10 1. of medium. $\dagger$ Expressed as a \% of culture dry weight.

In addition we have tested the fermentation and assimilation ability of all four cultures (Table 3 ).

The results indicate that cultures containing diploidization factor were unable to retain their constant smooth or rough character. Acriflavine was therefore added to cultures to obtain non-sporulating mutants. By this means a culture $(3 / 3 / \mathrm{I})$ which did not sporulate was obtained from strain 64/2 (Pl. I, fig. 6). Certain properties of this strain were compared with rough $(64 / \mathrm{I})$ and smooth $64 / 2$ strains (Table 4 ).

Strain $313 / 1$ gave only about $20 \%$ of the biomass of the parent culture $64 / 2$, while 
strains $64 / \mathrm{I}$ gave about $66 \%$ of the biomass of strain $64 / 2$. Rough strains $64 / \mathrm{I}$ contained threefold higher lipid content than the smooth strains $64 / 2$ and $3 / 3 / \mathrm{r}$.

The results of periodate oxidation (Table 5) and methylation analysis (Table 6) of extracellular and cellular water-soluble mannans from rough and smooth strains showed that they synthesized very similar branched mannans with $\alpha-(I \rightarrow 6), \alpha-(I \rightarrow 2)$ and $\alpha-(\mathrm{I} \rightarrow 3)$ glycosidic linkages and with equal chain length. These findings were verified by quantitative precipitation cross-reactions between rough and smooth strains of Saccharomyces cerevisiae IXL- $\mathrm{A}_{3}$ and antisera against the smooth strain of S. cerevisiae CCY 21-4-I3 (see Table 7).

Table 5. Physicochemical features and phosphorus content of extracellular and cellular mannans of rough and smooth strains of Saccharomyces cerevisiae

\begin{tabular}{|c|c|c|c|c|c|}
\hline \multirow[b]{2}{*}{ Culture } & & \multirow{2}{*}{$\begin{array}{l}{[\alpha]_{\mathrm{D}}^{24}} \\
\mathrm{H}_{2} \mathrm{O}\end{array}$} & \multirow{2}{*}{$\begin{array}{c}\mathbf{P} \\
(\%)\end{array}$} & \multicolumn{2}{|c|}{$\begin{array}{l}\text { Periodate oxidation } \\
\text { moles/I mannose unit }\end{array}$} \\
\hline & & & & $\mathrm{NaIO}_{4}$ & $\mathrm{HCOOH}$ \\
\hline R 64/l & $\begin{array}{l}\mathrm{EM} \\
\mathrm{CM}\end{array}$ & $\begin{array}{l}+74^{\circ} \\
+71^{\circ}\end{array}$ & $\begin{array}{l}0.40 \\
0.14\end{array}$ & $\begin{array}{l}1 \cdot 23 \\
1 \cdot 20\end{array}$ & $\begin{array}{l}0.29 \\
0.23\end{array}$ \\
\hline S $64 / 2$ & $\begin{array}{l}\mathrm{EM} \\
\mathrm{CM}\end{array}$ & $\begin{array}{l}+68^{\circ} \\
+75^{\circ}\end{array}$ & $\begin{array}{l}0.09 \\
0.10\end{array}$ & $\begin{array}{l}1 \cdot 13 \\
1 \cdot 17\end{array}$ & $\begin{array}{l}0.19 \\
0.23\end{array}$ \\
\hline $\mathrm{S}_{3} \mathbf{I}_{3 / 1}$ & $\begin{array}{l}\mathrm{EM} \\
\mathrm{CM}\end{array}$ & $\begin{array}{l}+75^{\circ} \\
+63^{\circ}\end{array}$ & $\begin{array}{l}0.12 \\
0.10\end{array}$ & $\begin{array}{l}1 \cdot 17 \\
1 \cdot 12\end{array}$ & $\begin{array}{l}0.16 \\
0.23\end{array}$ \\
\hline
\end{tabular}

EM, extracellular mannan; CM, cellular mannan.

Table 6. Methylation analysis of mannans from rough and smooth strains of Saccharomyces cerevisiae (mole \% composition)

\begin{tabular}{|c|c|c|c|c|}
\hline \multirow[b]{2}{*}{$O$-Methyl-D-mannose } & \multicolumn{2}{|c|}{ R 64/I } & \multicolumn{2}{|c|}{ S $64 / 2$} \\
\hline & $\begin{array}{l}\text { Cellular } \\
\text { mannan }\end{array}$ & $\begin{array}{l}\text { Extracellular } \\
\text { mannan }\end{array}$ & $\begin{array}{l}\text { Cellular } \\
\text { mannan }\end{array}$ & $\begin{array}{l}\text { Extracellular } \\
\text { mannan }\end{array}$ \\
\hline $\begin{array}{l}\text { 2,3,4,6-tetra- } \\
3,4,6 \text {-tri- }\end{array}$ & $\begin{array}{l}33 \cdot 8 \\
15 \cdot 8\end{array}$ & $\begin{array}{l}33 \cdot 3 \\
16 \cdot 4\end{array}$ & $\begin{array}{l}33 \cdot 9 \\
16 \cdot 4\end{array}$ & $\begin{array}{l}33 \cdot 5 \\
17 \cdot 1\end{array}$ \\
\hline $\begin{array}{l}\text { 3,4,6-tri- } \\
2,3,4 \text {-tri- }\end{array}$ & $\begin{array}{r}15 \cdot 8 \\
2.2\end{array}$ & $\begin{array}{r}2.4 \\
\end{array}$ & $\begin{array}{r}4 \\
2 \cdot 3\end{array}$ & $2 \cdot 4$ \\
\hline $2,4,6$-tri- & $16 \cdot 7$ & I $7 \cdot \mathrm{I}$ & I 5.9 & $15 \cdot 9$ \\
\hline 3,4-di- & $31 \cdot 5$ & $30 \cdot 8$ & $31 \cdot 5$ & $3 I \cdot I$ \\
\hline
\end{tabular}

Table 7. Consumption of extracellular and cellular mannans giving maximum precipitated antibody nitrogen of rabbit antiserum obtained by whole cells of Saccharomyces cerevisiae $2 I-4-13$

\begin{tabular}{|c|c|c|c|c|}
\hline Culture & $\begin{array}{l}\text { Extracellular } \\
\text { mannan } \\
(\mu \mathrm{g} .)\end{array}$ & $\begin{array}{l}\text { Precipitated } \\
\text { antibody } \\
\text { nitrogen } \\
(\mu \mathrm{g} .)\end{array}$ & $\begin{array}{c}\text { Cellular } \\
\text { mannan } \\
(\mu \mathrm{g} .)\end{array}$ & $\begin{array}{l}\text { Precipitated } \\
\text { antibody } \\
\text { nitrogen } \\
(\mu \mathrm{g} .)\end{array}$ \\
\hline $\begin{array}{l}21-4-13 \\
\text { R } 64 / 1 \\
\text { S } 64 / 2 \\
\text { S } 313 / 1\end{array}$ & $\begin{array}{l}150 \\
150 \\
100 \\
150\end{array}$ & $\begin{array}{l}730 \\
810 \\
690 \\
690\end{array}$ & $\begin{array}{l}150 \\
150 \\
100 \\
150\end{array}$ & $\begin{array}{l}730 \\
660 \\
690 \\
850\end{array}$ \\
\hline
\end{tabular}

Zakharov \& Inge-Vechtomov (1966) studied the genetic background of rough and smooth phenotypes of Saccharomyces cerevisiae, while Vezinhet, Galzy \& Durand (1968) examined the metabolic differences between the two types. The roughness of 
colonies is recessive and the smoothness dominant or semidominant. Šilhánková (I969) supposes the existence of metabolic suppressors of the rough phenotype responsible for the instability of rough mutants. Suppression of the rough phenotype in mutants requiring tryptophan or lysine for the growth falls into this category. Recently Thieme and Ballou (1970) have found that mannans produced by diploid heterothallic strains of Saccharomyces cerevisiae contain longer chains than the mannans from haploid strains. On the other hand, we have found that mannans from our monosporic cultures of $S$. cerevisiae IXL-A 3 possess the same average chain length. We explain this fact by the homothallic character of our strains. The indication of this homothally is the presence of diploidization gene $\mathrm{D}$.

Rough strains (Table 4) contained higher amounts of lipids than smooth strains. During aerobic conditions carbohydrates are metabolized into lipids by yeasts but anaerobically grown culture require the incorporation of an unsaturated fatty acid in the medium, i.e. oleic or linoleic acid (Babij, Moss \& Ralph, 1969).

We are grateful to Dr L. Sedlárová for her isolation of monosporogenous cultures.

\section{REFERENCES}

BABOR, K., KALÁČ, V. \& TifLÁRIK, K. (1964). Iodometric determination of small quantities of formic acid with the use of amperometric indication. Chemické zvesti $18,913-917$.

Babi,, R., Moss, F. J. \& RalPH, B. J. (1969). Effects of oxygen and glucose levels on lipid composition of yeast Candida utilis grown in continuous culture. Biotechnology and Bioengineering 9, $593-603$.

Croon, I. Herrström, G., Kull, G. \& Lindberg, B. (1960). Demethylation and degradation of sugars in acid hydrolysis. Acta chimica scandinavica 14, I338-1342.

Fiske, C. H. \& SubBarow, Y. (I925). Colorimetric determination of phosphorus. Journal of Biological Chemistry 66, 375-400.

Fleury, P. \& Lange, J. (I933). Sur le dosage de l'acide periodique en présence de l'acide iodique. Journal de pharmacie et de chimie 17, I07-113.

Folch, J., Lee, M. \& Sloane-Stanley, G. H. (1957). A simple method for the isolation and purification of total lipids from animal tissues. Journal of Biological Chemistry 226, 497-509.

HAwORTH, W. N. (I9I5). A new method of preparing alkylated sugars. Journal of the Chemical Society I07, 8-I6.

Haworth, W. N., Hirst, E. L. \& Isherwood, F. A. (1937). Polysaccharides. 24. Yeast mannan. Journal of the Chemical Society, pp. 784-79I.

Kauppinen, V., Kiviniemi, K. \& ERkama, J. (I965). Cell wall composition of smooth and rough forms of Candida guilliermondii. Suomen kemistilehti $3^{8 \mathbf{8}, 3-5 .}$

Kocková-Kratochvílová, A. (1954). Practice of Technical Microbiology. Prague: Statni nakladatelstvi technicke literatury.

Kocková-Kratochvílová, A. \& Pokorná, M. (1964). Species morphotypization of the Saccharomyces genus. Biologia 19, 778-791.

Kreger-van RiJ, N. J. W. (I969). Taxonomy and systematics of yeasts. In The Yeasts, vol. I Biology of yeasts, p. 7. Edited by A. H. Rose and J. S. Harrison. London and New York: Academic Press.

Kuhn, R., Trischmann, H. \& Löw, I, (1955). Zur Permethylierung von Zuckern und Glykosiden. Angewandte Chemie 67, 32.

LeTTERS, R. (1966). Phospholipids of yeast. Extraction, isolation and characterization of yeast phospholipids. Biochimica et biophysica acta 116, 489-499.

LÜDERTTZ, O. \& WeSTPHAL, O. (1966). Die Bedeutung von Mutanten bei Enterobacteriaceen für die chemische Erforschung ihrer Zellwand-Polysaccharide. Angewandte Chemie 78, 172-I85.

MASLER, L., ŠIKL, D., BAUER, S. \& ŠANDULA, J. (1966). Extracellular polysaccharide-protein complexes produced by selected strains of Candida albicans (Robin) Berkhout. Folia microbiologica Ir, 373378. 


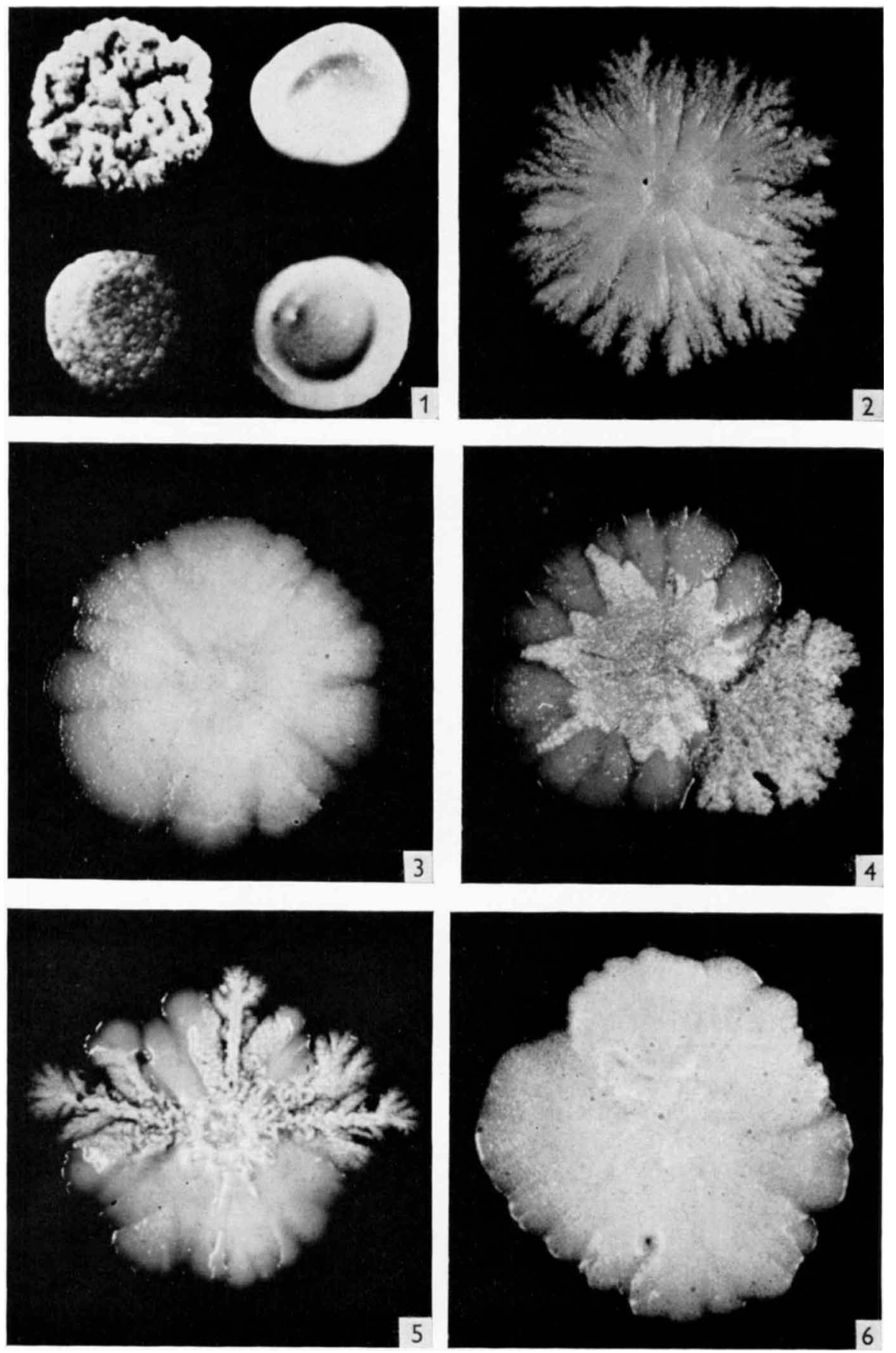

L. MASLER, D. ŠIKL, A. KOCKOVÁ-KRATOCHVÍLOVÁ AND Š. BAUER (Facing p. 19I) 
Millbank, J. W. \& Macrae, R. M. (1964). Degradation of yeast cell wall by fractionated snail gut enzyme. Nature, London 20I, I347.

PAtridge, S. M. (1949). Aniline hydrogen phtalate as a spraying reagent for chromatography of sugars. Nature, London 164, 443.

Sweeley, C. L., Bentley, R., Makita, M. \& Wels, W. W. (1963). Gas-liquid chromatography of trimethylsilyl derivatives of sugars and related substances. Journal of the American Chemical Society $85,2497-2507$.

ŠILHÁNKovÁ, L. (1957). The Effect of Surface-active Compounds on Rough and Smooth Yeast Forms. C.Sc. Thesis, Prague.

ŠILHÁNKovÁ, L. (1969). Suppression of rough phenotype in Saccharomyces cerevisiae. Antonie van Leeuwenhoek 35, Supplement: Yeast Symposium, C I I-C I 2.

THIEME, T. R. \& BALLOU, C. E. (1970). Constancy of the cell wall mannan structure of Saccharomyces cerevisiae. Biochemical and Biophysical Research Communications 39, 621-625.

Vezinhet, F., Galzy, P. \& DuRAND, J. (I968). Variation phenotypique de Saccharomyces cerevisiae Hansen au cours d'une culture prolongée sur acide pyruvique. Comptes rendus des séances de la Société de biologie 162, 1572-1575.

Wickerham, L. J. \& Barton, K. A. (1962). Phylogeny and biochemistry of the genus Hansenula. Bacteriological Reviews 26, 382-397.

Zakharov, I. A. \& InGE-Vechromov, S. G. (1966). Genetics of roughness in the yeasts. Genetica 8, II2-II8.

\section{EXPLANATION OF PLATE}

Fig. I. Cultures arising from the individual spores of one ascus of Saccharomyces cerevisiae.

Fig. 2. Rough strain obtained from original monosporic culture 64/1.

Fig. 3. Smooth strain obtained from original monosporic culture $64 / 2$.

Fig. 4. Mixture of rough and smooth strains obtained from original monosporic culture $64 / 3$.

Fig. 5. Mixture of rough and smooth strains obtained from original monosporic culture 64/4.

Fig. 6. Smooth strain which did not sporulate obtained by means of acriflavine from smooth strain $64 / 2$. 